\title{
Megaloblastic anaemia of pregnancy: a clinical and laboratory study with particular reference to the total and labile serum folate levels
}

\author{
P. G. RAE ${ }^{1}$ AND P. M. ROBB
}

From the Department of Obstetrics and Department of Haematology, Walton Hospital, Liverpool

SYNOPSIS It has been shown that the incidence of megaloblastic anaemia in a group of 463 randomly selected pregnant women receiving iron was 12 times as high as in a control group of 235 pregnant women receiving iron and folic acid. The incidence of all types of anaemia in the women receiving iron alone was more than three times the incidence in those having iron and folic acid. Some women who were not anaemic or who had normoblastic anaemia had serum folate levels in the same range as the women with megaloblastic anaemia, but none of the women with megaloblastic anaemia had high serum folate levels. The labile fraction of the serum folate was no more reliable than the total serum folate as a diagnostic criterion of megaloblastic erythropoiesis in the individual case. The blood group distribution in the women with megaloblastic anaemia was the same as in the general population. Babies born to mothers with megaloblastic anaemia tended to be smaller than the rest, although there was no difference in the placental weights.

The significance of these findings is discussed.

Megaloblastic erythropoiesis, with a varying degree of anaemia, is now known to be common in pregnancy. Although erythropoiesis is restored to normal by folic acid, estimation of the total serum folate is not a reliable guide to diagnosis, as it is in other folate-deficiency states such as steatorrhoea. It has been claimed that the level of the labile fraction of the serum folate (probably 5-methyl-tetrahydrofolic acid) is a reliable diagnostic criterion (Ball and Giles, 1964; Giles, 1966). If this is so, then an important factor in the pathogenesis of megaloblastic anaemia of pregnancy would seem to be an inability to metabolize folate compounds to their most useful form.

There have been conflicting reports about the incidence of serious complications such as toxaemia, abortion, antepartum haemorrhage, and premature labour in pregnant women with megaloblastic anaemia (Gatenby and Lillie, 1Present address: Mill Road Maternity Hospital, Liverpool Received for publication 21 October 1969.
1960; Mackenzie and Abbott, 1960; Hibbard and Hibbard, 1963; Martin, Harper, and Kelso, 1965; Giles, 1966).

Some workers have found an abnormally high incidence of blood group $A$ in megaloblastic anaemia of pregnancy, and this has been taken to support the suggestion that a predisposition to the condition may be inherited (Giles, 1966).

We embarked on the work reported here to find out (1) whether the incidence of megaloblastic anaemia of pregnancy was as high in north Liverpool as in other similar industrial areas; (2) whether, in the patients not prescribed folic acid, the labile fraction of the serum folate was a more satisfactory diagnostic criterion of megaloblastic anaemia than the total serum folate; (3) whether, in north Liverpool, megaloblastic anaemia of pregnancy was associated with other serious complications of pregnancy, and (4) whether there was an abnormally high incidence of blood group $A$ in our patients with megaloblastic anaemia of pregnancy. 


\section{Material and Methods}

The catchment area served by the hospital in which this work was carried out is highly industrial. The patients are almost exclusively from social classes IV and V. There is a high proportion of Roman Catholics in the area which is, in part, responsible for the prevalence of grand multiparity amongst the patients. Obesity and poor dietary habits are common. Many patients exist on a diet consisting largely of carbohydrates with very little protein and fat. It is not unusual for a well balanced meal to be taken only once a week, and for the favourite meals at other times to consist of a chip sandwich and a cup of tea.

In spite of the low social class of most of the patients the economic status is often unexpectedly high, because of the nature of the work which is available locally and the high earning capacity of the large family units. The income is often misapplied so that the basic factors for a healthy life, such as hygiene, a balanced diet, and adequate clothing are considered after other, less important, interests have been satisfied.

The social picture is reflected in the poor attendances at the antenatal clinic of those patients who are most at risk. The same patients are reluctant to cooperate in prophylactic, and even therapeutic, treatment.

\section{SELECTION OF PATIENTS}

In the 12 months beginning in January 1965, a control group of women taking iron and folic acid throughout pregnancy was compared with a test group taking iron alone. Patients were allocated at random to one or other of the two groups, depending on which day of the week they attended the antenatal clinic. Those attending on a Monday were prescribed ferrous gluconate, $200 \mathrm{mg}$, tds, throughout pregnancy; those attending on a Tuesday were prescribed the same dose of ferrous gluconate in addition to folic acid, $5 \mathrm{mg}$ tds. Patients were admitted to the Monday group at any stage of pregnancy, provided that we were sure that folic acid had not been taken before the first visit to the antenatal clinic. The patients were questioned about this and if there was any doubt about the identity of treatment taken, they were not admitted to the series. The Tuesday group was limited to patients seen initially during the first trimester because we had to be sure that they were prescribed folic acid throughout pregnancy.

The Monday group (463 patients) was, therefore, larger than the Tuesday group (235 patients).

\section{COLLECTION OF BLOOD AND MARROW}

Samples of venous blood were taken from patients in both groups at the first visit to the antenatal clinic, at the 32nd and 36th weeks of pregnancy, and during the first three days of the puerperium. Serum from the patients who did not take folic acid was stored (see below) for possible folate estimations. Total and labile serum folate levels were estimated in the patients whose marrows were examined (see below) and in some 'nonanaemic' patients selected at random from those not receiving folic acid. Folate studies were not made on serum collected from patients who did take folic acid.

Blood from all patients in both groups was examined for haemoglobin concentration within 24 hours of collection. If the concentration was below the arbitrarily chosen level of $10.9 \mathrm{~g}$ per $100 \mathrm{ml}$, the sternal marrow was examined. If erythropoiesis proved to be megaloblastic, folic acid was prescribed for the remainder of the pregnancy; if erythropoiesis was normoblastic, oral or parenteral iron was given.

Folate estimations were also made in some patients who were not in either of our two trial groups, but were discovered to have megaloblastic anaemia of pregnancy while the investigation was in progress. We did not, of course, have serum for folate estimation taken at earlier stages of pregnancy in these patients, and they were not included in our assessment of the incidence of the disease nor of the complications associated with it.

\section{CLASSIFICATION OF PATIENTS}

Patients with a haemoglobin concentration of $10.9 \mathrm{~g}$ per $100 \mathrm{ml}$ or more were classified 'not anaemic', and those with a haemoglobin concentration of under $10.9 \mathrm{~g}$ per $100 \mathrm{ml}$ were classified 'normoblastic' or 'megaloblastic' according to the marrow smear. The megaloblastic group was further subdivided into grade 3 (floridly megaloblastic), grade 2 (true megaloblasts present but erythropoiesis largely normoblastic), or grade 1 (no true megaloblasts, but at least two of the following features, namely, transitional megaloblasts, macronormoblasts, Howell-Jolly bodies in some of the red cell precursors, giant metamyelocytes). A further group of 'unclassified' patients comprised 45 women with a haemoglobin level of under $10.9 \mathrm{~g}$ per $100 \mathrm{ml}$, whose sternal marrow was not, for various reasons, examined.

In an attempt to overcome bias in interpreting marrow smears, we adopted the following procedure. The marrow smears were examined at once, since the patient's management depended on the result. All smears were then taken and stored by a secretary, who gave each a code number. Months later, at the end of the trial, all the coded smears were graded by one of us (P.M.R.), the patient's name being unknown to the microscopist. Approximately eight weeks later, the coded smears were re-examined by P.M.R. without reference to the grade given at the first examination. The gradings from the two examinations were then compared, the patient's identity remaining unknown. After the lapse of several more weeks, the few smears where the 
two gradings had not coincided were again examined and regraded. The final grading was that given on at least two occasions. Not till after the final grading was given was the code broken and the patient's name matched to the smear.

\section{LABORATORY TECHNIQUES}

Venous specimens were used for the haemoglobin estimation, which was done by the cyanmethaemoglobin technique.

We used Lactobacillus casei for assaying the serum folate. Our method was based on that of Spray (1964) with some modifications.

Cowan, Hoffbrand, and Mollin (1966) showed that serum extracts enhance the growth of Lactobacillus casei more than can be accounted for by the folate content of the extracts. Our own experiments confirmed this and showed that the non-specific growth-enhancing effect was less when high dilutions of serum extract were used, and less after a long ( 40 hours) than after a short (18 hours) incubation period. We therefore used high dilutions of serum extract (1/96 and 1/92) and an incubation period of $\mathbf{4 0}$ hours. To reduce the contamination of the unknown serum by folate carried in or on the lactobacilli, the organisms were depleted of folate by being grown in a folate-free medium for five to six hours before the assay. These features of our method resulted in lower overall values than have been found by some other workers. (Our range of normal for healthy non-pregnant young women is $1.3-8.5 \mathrm{ng} / \mathrm{ml}$ total serum folate, with a geometric mean of $3.3 \mathrm{ng} / \mathrm{ml}$ and an arithmetic mean of $3.6 \mathrm{ng} / \mathrm{ml}$ ). Full details of our assay method are given in the Appendix.

\section{Results}

\section{INCIDENCE OF ANAEMIA}

As shown in Table I, the incidence of anaemia of all kinds was more than three times higher (146 patients, $31.5 \%$ ) in women taking iron alone than it was in those taking both iron and folic acid (23 patients, $9 \cdot 8 \%$ ). Megaloblastic erythropoiesis was found in 42 patients $(9.1 \%)$ who did not take folic acid, and in two for whom folic acid had

\begin{tabular}{|c|c|c|}
\hline & $\begin{array}{l}\text { Iron-treated } \\
\text { Group }\end{array}$ & $\begin{array}{l}\text { Iron- and } \\
\text { Folic-acid- } \\
\text { treated Group }\end{array}$ \\
\hline $\begin{array}{l}\text { Total number of patients } \\
\text { Anaemia }\end{array}$ & 463 & 235 \\
\hline $\begin{array}{l}\text { All types } \\
\text { Megaloblastic anaemia } \\
\text { Normoblastic anaemia } \\
\text { Unclassified anaemia }\end{array}$ & $\begin{array}{r}146(31.5 \%) \\
42(9.1 \%) \\
59(12.7 \%)\end{array}$ & $\begin{array}{r}23(9.8 \%) \\
2(0.8 \%) \\
21(9.0 \%)\end{array}$ \\
\hline $\begin{array}{l}\text { (No marrow studies) } \\
\text { Never anaemic }\end{array}$ & $\begin{array}{r}45(9 \cdot 7 \%) \\
317(68 \cdot 5 \%)\end{array}$ & $\overline{212}(\overline{90 \cdot 2} \%)$ \\
\hline
\end{tabular}

Table I Incidence of anaemia been prescribed. It was doubtful if these patients had taken their tablets although they would no $\overline{\bar{E}}$ admit to this. We formed the opinion that thex were not reliable witnesses.

Unless specifically stated to the contrary, als. results presented from here onwards refer to the trial group of patients, namely, those who were prescribed iron alone.

Included in the 146 patients $(31.5 \%)$ who were anaemic are 45 patients $(9.7 \%)$ whose marrows were not examined. It is likely that some of these women may have had megaloblastic anaemia, so' that the true incidence of this condition may haves been even higher than $9 \cdot 1 \%$.

\section{TIME OF ONSET OF ANAEMIA}

Our results confirm those of other workers whoi demonstrated that megaloblastic anaemia is more likely to occur as pregnancy advances (Hibbardu and Hibbard, 1968). Thirty-three $(80 \%)$ of ouro patients with megaloblastic anaemia developed? the condition in the third trimester and a furthersix $(14 \%)$ in the puerperium.

\section{SEVERITY OF ANAEMIA}

None of our patients with normoblastic anaemia had a haemoglobin concentration of less thano $7 \cdot 25 \mathrm{~g}$ per $100 \mathrm{ml}$ at any stage of pregnancy or the puerperium. However, of eight patients witho grade 2 or 3 megaloblastic erythropoiesis, threeo $(37.5 \%)$ had a haemoglobin concentration of less than $7 \cdot 27 \mathrm{~g}$ per $100 \mathrm{ml}$.

In general, we found that as erythropoiesis 3 became more megaloblastic, so did the severity of the anaemia increase.

In the 23 patients prescribed iron and folic acid who did become anaemic the lowest haemo-i globin concentration discovered was $8.45 \mathrm{~g}$ per3 $100 \mathrm{ml}$.

TOTAL AND LABILE SERUM FOLATE LEVELS AT DIFFERENT STAGES OF PREGNANCY ANDO IN THE THREE HAEMOPOIETIC GROUPS

In the non-anaemic group, the geometric mean of the total and labile folates was higher in then second than in the first trimester; apart from this, N the geometric mean of the folate levels in all $\sigma$ three groups fell as pregnancy advanced (Figs, $1 \mathrm{a}$ and $1 \mathrm{~b}$ ).

From the second trimester onwards the geo- $\infty$ metric mean of the total serum folate levels was highest in the non-anaemic group, lower in the ${ }^{-}$ normoblastic group, and lower still in the megaloblastic group (Fig. 1a). The numbers of first- $\frac{\vec{D}}{\mathrm{D}}$ trimester specimens available for folate estimation $\frac{\circ}{\sigma}$ in the normoblastic and megaloblastic groups were small (five normoblastic and three megalo- $\delta$ blastic), so that we cannot attach much significance? to the first trimester geometric means in theseo groups. While there was, from the second tri- $?$ mester onwards, a correlation between the 


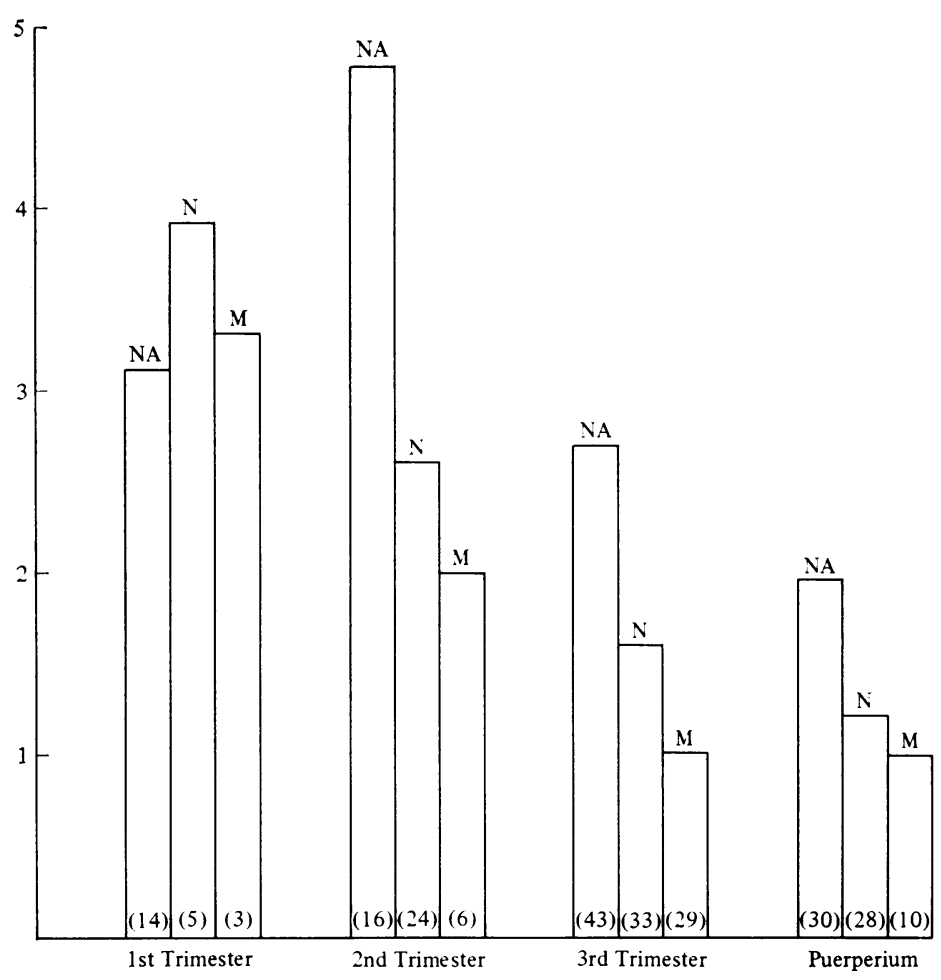

Fig. 1a

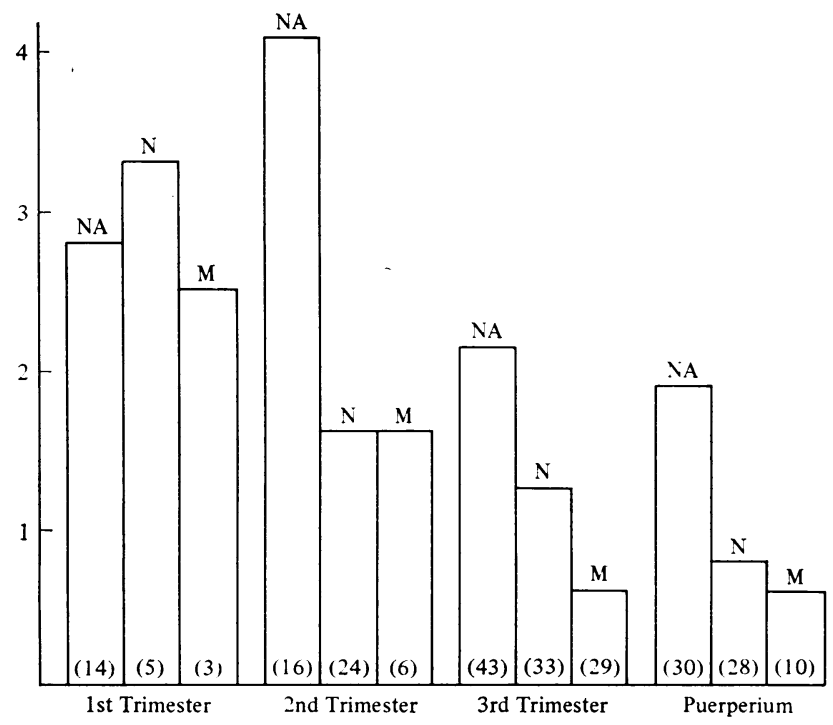

Fig. 1b

Figs. 1a and 1b Geometric means of total (1a) and labile (1b) serum folates grouped according to stage of pregnancy. $N A=$ no anaemia,$N=$ normoblastic anaemia, $M=$ megaloblastic anaemia. The figures in brackets denote the numbers of sera tested, eg, 14 sera from non-anaemic women in the first trimester. ('Normoblastic' and 'megaloblastic' refer to the patient's eventual classification; she did not necessarily have normoblastic (or megaloblastic) anaemia at the time when the sample was taken.) haemoglobin level and type of anaemia on the $\stackrel{c}{\complement}$ one hand, and the geometric mean of the total $\overline{\bar{F}}$ serum folates on the other, there was much $D$ overlap between the serum folate levels in the $\frac{0}{\overrightarrow{0}}$ three haemopoietic groups (Figs. $2 \mathrm{a}, 2 \mathrm{~b}, 2 \mathrm{c}$, and $\stackrel{\text { ㅇ }}{\text {. }}$ 2d).

The labile serum folate followed much the same pattern as the total serum folates (Figs. 1b, 3a, 3b, 3c, 3d).

Table II sets out the geometric means and range $\frac{D}{\vec{D}}$ of the total and labile serum folates at the various $\propto$ stages of pregnancy, together with a standard $\%$ deviation factor which is the antilogarithm of the $\vec{\circ}$ standard deviation of the logarithm of the folate values. The geometric rather than the arithmetic $\vec{\omega}$ mean has been used as it is a more satisfactory estimation when the data being analysed have, $?$ as here, a skew distribution; and for the same $\underset{\omega}{N}$ reason we have given a standard deviation factor $r$ based on the logarithms of the folate values.

These geometric means were calculated from

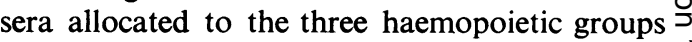
according to the eventual classification of the $\overrightarrow{\vec{c}}$ patient from whom the serum was taken. Thus a $\frac{\subseteq}{<}$ serum was allocated to the 'normoblastic' or 'megaloblastic' group if the patient from whom it came developed normoblastic or megaloblastic. anaemia at any stage of pregnancy; she did not necessarily have normoblastic (or megaloblastic) anaemia at the stage when that particular serum sample was taken. We thought that it would be interesting to repeat the calculations, limiting the $\propto$ data in the normoblastic and megaloblastic groups $\overrightarrow{\overrightarrow{\hat{O}}}$ to folate levels estimated at the time the marrow 3 was aspirated, ie, including in the normoblastic and megaloblastic groups only those sera whose donors were known to have normoblastic (or megaloblastic) anaemia respectively at the stage when the serum was taken. These results are set 3 out in Figures $4 \mathrm{a}$ and $4 \mathrm{~b}$. They confirm the tendency of the folate levels in the normoblastic group to fall as pregnancy advances. No conclusions can be drawn about the correlation of folate levels to stage of pregnancy in the megalo- $\frac{D}{0}$ blastic groups as all the sera except one are from the third trimester or the puerperium. Sur- $\mathcal{O}$ prisingly, the folate levels in the more severely $N$ megaloblastic grades differ little from those in the less severe grades.

The individual total and labile folate levels of sera taken at the same time as the marrow was $\stackrel{O}{=}$ aspirated are illustrated in Figures $5 \mathrm{a}, 5 \mathrm{~b}, 5 \mathrm{c}, \stackrel{\oplus}{\oplus}$ and $5 \mathrm{~d}$. There is a considerable overlap between : the normoblastic and megaloblastic groups, and between the less and the more severely megalo- $\overrightarrow{\mathbb{D}}$ blastic grades, both in the third trimester and in $\frac{?}{\mathbb{Q}}$ the puerperium, and this overlap remains whether $\cong$ we use the total or the labile serum folate for comparison.

Table III sets out the geometric means and range of the total and labile folate levels of the sera taken at the same time as the marrow was aspirated, and gives a standard deviation factor. 


\begin{tabular}{|c|c|c|c|c|c|c|c|c|}
\hline \multirow[t]{2}{*}{ Stage of Pregnancy } & \multicolumn{2}{|c|}{ Number of Estimations } & \multicolumn{2}{|c|}{ Geometric Mean } & \multicolumn{2}{|c|}{$\begin{array}{l}\text { Standard Deviation } \\
\text { Factor }^{1}\end{array}$} & \multicolumn{2}{|c|}{ Range (ng folate) } \\
\hline & Total & Labile & Total & Labile & Total & Labile & Total & Labile \\
\hline $\begin{array}{c}\text { First Trimester } \\
\text { Not anaemic } \\
\text { Normoblastic } \\
\text { Megaloblastic }\end{array}$ & $\begin{array}{r}14 \\
5 \\
3\end{array}$ & $\begin{array}{r}14 \\
5 \\
3\end{array}$ & $\begin{array}{l}3 \cdot 105 \\
3 \cdot 867 \\
3 \cdot 281\end{array}$ & $\begin{array}{l}2 \cdot 786 \\
3 \cdot 318 \\
2 \cdot 497\end{array}$ & $\begin{array}{l}1 \cdot 565 \\
2 \cdot 063 \\
2 \cdot 254\end{array}$ & $\begin{array}{l}1 \cdot 615 \\
2 \cdot 689 \\
3 \cdot 110\end{array}$ & $\begin{array}{l}1 \cdot 3-5 \cdot 8 \\
1 \cdot 1-6 \cdot 7 \\
1 \cdot 5-7 \cdot 6\end{array}$ & $\begin{array}{l}1 \cdot 1-5 \cdot 4 \\
0 \cdot 6-6 \cdot 6 \\
0 \cdot 8-7 \cdot 4\end{array}$ \\
\hline $\begin{array}{c}\text { Second Trimester } \\
\text { Not anaemic } \\
\text { Normoblastic } \\
\text { Megaloblastic }\end{array}$ & $\begin{array}{r}16 \\
24 \\
6\end{array}$ & $\begin{array}{r}16 \\
24 \\
6\end{array}$ & $\begin{array}{l}4 \cdot 814 \\
2 \cdot 639 \\
1 \cdot 954\end{array}$ & $\begin{array}{l}4 \cdot 102 \\
1 \cdot 599 \\
1 \cdot 592\end{array}$ & $\begin{array}{l}1 \cdot 941 \\
2 \cdot 095 \\
2 \cdot 709\end{array}$ & $\begin{array}{l}2 \cdot 356 \\
2 \cdot 292 \\
2 \cdot 999\end{array}$ & $\begin{array}{l}2 \cdot 0-32 \cdot 0 \\
0 \cdot 9-9 \cdot 7 \\
0 \cdot 6-7 \cdot 7\end{array}$ & $\begin{array}{l}0 \cdot 6-32 \cdot 0 \\
0 \cdot 4-7 \cdot 7 \\
0 \cdot 5-7 \cdot 6\end{array}$ \\
\hline $\begin{array}{c}\text { Third Trimester } \\
\text { Not anaemic } \\
\text { Normoblastic } \\
\text { Megaloblastic }\end{array}$ & $\begin{array}{l}43 \\
33 \\
29\end{array}$ & $\begin{array}{l}43 \\
33 \\
29\end{array}$ & $\begin{array}{l}2.656 \\
1.626 \\
0.988\end{array}$ & $\begin{array}{l}2 \cdot 152 \\
1 \cdot 257 \\
0 \cdot 616\end{array}$ & $\begin{array}{l}2 \cdot 122 \\
1 \cdot 837 \\
1 \cdot 684\end{array}$ & $\begin{array}{l}2 \cdot 328 \\
1.951 \\
2 \cdot 433\end{array}$ & $\begin{array}{l}0 \cdot 6-32 \cdot 0 \\
0 \cdot 5-4 \cdot 2 \\
0 \cdot 4-2 \cdot 6\end{array}$ & $\begin{array}{l}0 \cdot 4-32 \cdot 0 \\
0 \cdot 4-3 \cdot 9 \\
0 \cdot 1-2 \cdot 2\end{array}$ \\
\hline $\begin{array}{l}\text { Puerperium } \\
\text { Not anaemic } \\
\text { Normoblastic } \\
\text { Megaloblastic }\end{array}$ & $\begin{array}{l}30 \\
26 \\
10\end{array}$ & $\begin{array}{l}30 \\
26 \\
10\end{array}$ & $\begin{array}{l}1 \cdot 947 \\
1 \cdot 170 \\
1 \cdot 042\end{array}$ & $\begin{array}{l}1 \cdot 918 \\
0.766 \\
0.567\end{array}$ & $\begin{array}{l}2 \cdot 170 \\
1 \cdot 791 \\
1 \cdot 816\end{array}$ & $\begin{array}{l}2 \cdot 632 \\
2 \cdot 343 \\
2 \cdot 675\end{array}$ & $\begin{array}{l}0 \cdot 5-17 \cdot 0 \\
0 \cdot 5-4 \cdot 7 \\
0 \cdot 5-3 \cdot 7\end{array}$ & $\begin{array}{l}0 \cdot 2-16 \cdot 2 \\
0 \cdot 04-4 \cdot 4 \\
0 \cdot 1-3 \cdot 4\end{array}$ \\
\hline
\end{tabular}

Table II Geometric means and range of total and labile serum folate levels at different stages of pregnancy 'Standard deviation factor is the antilogarithm of the standard deviation of the logarithm of the folate values.

\begin{tabular}{|c|c|c|c|c|c|c|c|c|}
\hline \multirow[t]{2}{*}{ Stage of Pregnancy } & \multicolumn{2}{|c|}{$\begin{array}{l}\text { Number of } \\
\text { Estimations }\end{array}$} & \multicolumn{2}{|c|}{ Geometric Mean } & \multicolumn{2}{|c|}{$\begin{array}{l}\text { Standard Deviation } \\
\text { Factor }\end{array}$} & \multicolumn{2}{|c|}{ Range (ng folate) } \\
\hline & Total & Labile & Total & Labile & Total & Labile & Total & Labile \\
\hline \multicolumn{9}{|l|}{ Third Trimester } \\
\hline Normoblastic & 31 & 31 & 1.622 & $1 \cdot 288$ & $2 \cdot 119$ & 1.964 & $0 \cdot 5-4 \cdot 2$ & $0.4-3.9$ \\
\hline Megaloblastic (all) & 30 & 30 & 0.987 & 0.617 & $1 \cdot 669$ & $2 \cdot 226$ & $0 \cdot 4-2 \cdot 6$ & $0 \cdot 1-2 \cdot 2$ \\
\hline Megaloblastic (group 1) & 26 & 26 & $1 \cdot 263$ & 0.653 & 1.650 & 2.399 & $0.4-2 \cdot 6$ & $0 \cdot 1-2 \cdot 2$ \\
\hline Megaloblastic (groups 2 and 3) & 4 & 4 & 0.714 & 0.428 & $1 \cdot 702$ & 2.435 & $0 \cdot 4-1 \cdot 3$ & $0 \cdot 2-1 \cdot 2$ \\
\hline \multicolumn{9}{|l|}{ Puerperium } \\
\hline Normoblastic & 6 & 6 & $1 \cdot 104$ & 0.638 & $1 \cdot 616$ & 2.424 & $0.9-2 \cdot 4$ & $0 \cdot 2-2 \cdot 0$ \\
\hline Megaloblastic (all) & 10 & 10 & $1 \cdot 042$ & 0.568 & 1.816 & 3.058 & $0 \cdot 5-3 \cdot 7$ & $0 \cdot 1-3 \cdot 4$ \\
\hline Megaloblastic (group 1) & 5 & 5 & 1.037 & 0.671 & 1.569 & 2.076 & $0 \cdot 7-2 \cdot 0$ & $0 \cdot 3-1 \cdot 2$ \\
\hline Megaloblastic (groups 2 and 3) & 5 & 5 & 1.049 & 0.480 & $2 \cdot 167$ & $3 \cdot 523$ & $0 \cdot 5-3 \cdot 7$ & $0 \cdot 1-3 \cdot 4$ \\
\hline
\end{tabular}

Table III Geometric means and ranges of total and labile folate levels of sera taken at time of marrow aspiration

\section{ASSOCIATION WITH OTHER COMPLICATIONS UF PREGNANCY}

None of our patients with megaloblastic anaemia carried a multiple pregnancy.

Two patients $(4 \%)$ with megaloblastic anaemia suffered abruptio placentae compared with one patient $(1.7 \%)$ in the group with normoblastic anaemia. The numbers involved are too small for reliable statistical analysis. None of the patients in the other groups had an accidental haemorrhage.

There was no difference in the incidences of postpartum haemorrhage, pre-eclampsia, premature labour, and stillbirths in any of the groups.

\section{BLOOD GROUP DISTRIBUTION}

In our series, the blood group distribution in patients with megaloblastic anaemia corresponded closely with the distribution in the general population on Merseyside (Table IV).

\begin{tabular}{llll}
\hline $\begin{array}{l}\text { General Population } \\
\text { of Liverpool }(\%)\end{array}$ & $\begin{array}{l}\text { Expected Nos. in } \\
\text { 48 Cases of } \\
\text { Megaloblastic } \\
\text { Anaemia }\end{array}$ & $\begin{array}{l}\text { Actual Nos. Found } \\
\text { in 48 Cases of } \\
\text { Megaloblastic } \\
\text { Anaemia }\end{array}$ \\
\hline A & 38.4 & 18.4 & 16 \\
O & 49.8 & 23.9 & 27 \\
B & 9.04 & 4.3 & 5 \\
AB & 2.71 & 1.3 & 0
\end{tabular}

Table IV Arithmetic means of the birth weights

woman more likely to develop anaemia, particularly if her pregnancies have followed on with? short intervals between them. Figure 6 shows theo relationship between parity and the type of erythropoiesis in our patients.

Of 196 primigravidae, 135 patients $(72.5 \%)$ 궁 were never anaemic whereas only $29(49 \%)$ of 59 웅 grand multiparae escaped this complication. Increasing parity was associated with increased $\stackrel{\mathbb{Q}}{\varrho}$ incidences of both normoblastic and megaloblastic erythropoiesis.

BIRTH WEIGHTS OF BABIES

It is known that increasing parity predisposes towards large infant birth weights. Because 


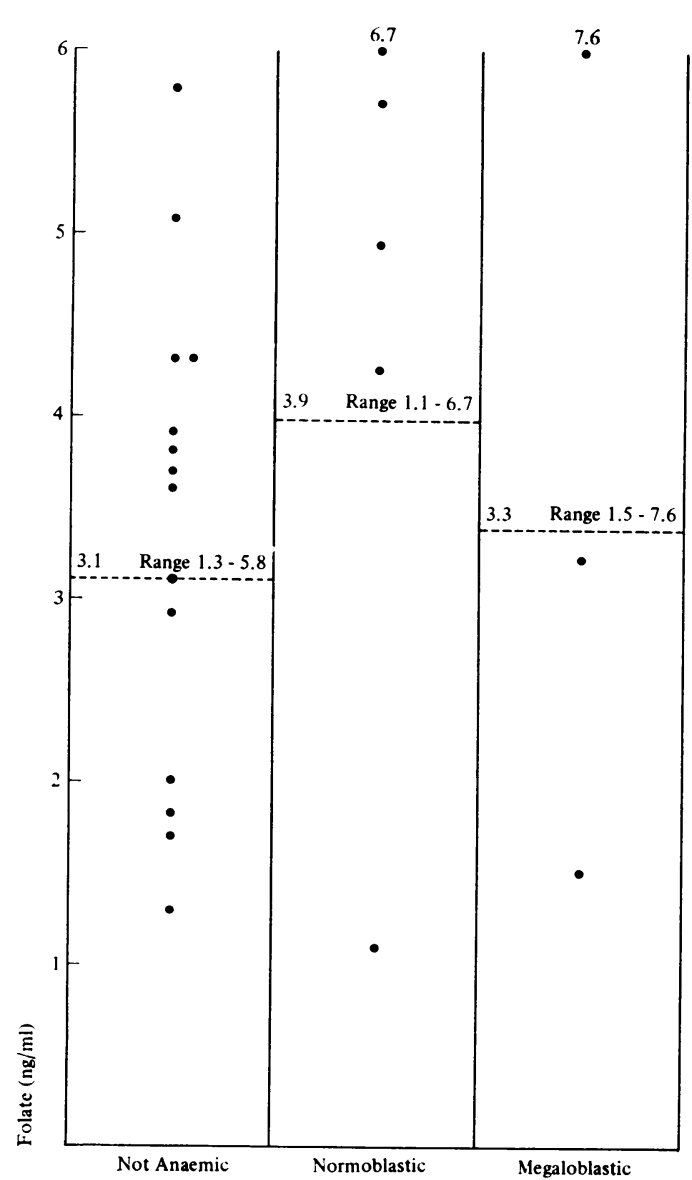

Fig. 2a

Figs. 2a, 2b, 2c, and 2d Total serum folates in the various stages of pregnancy, grouped according to type of erythropoiesis. $2 a=$ first trimester, $2 b=$ second trimester, $2 c=$ third trimester, and $2 d=$ puerperium. ('Normoblastic' and 'megaloblastic' refer to the patient's eventual classificiation; she did not necessarily have normoblastic (or megaloblastic) anaemia at the time the sample was taken). Dotted line represents the geometric mean. As the diagram does not go above $6 \mathrm{ng}$, values above this level are marked at 6 with the actual level written above the dot.

megaloblastic anaemia is more common in grand multiparae, it might be expected that these patients would deliver heavier babies than those with normoblastic erythropoiesis. Table $\mathrm{V}$ shows the median values of the birth weights of the babies born in the three parity groups. Each of these groups has been further broken down to show the effect of maternal erythropoiesis on the infant birth weight. It is clear that there is a tendency for patients with megaloblastic anaemia to have babies with lower birth weights than expected. Table VI shows the arithmetic means of

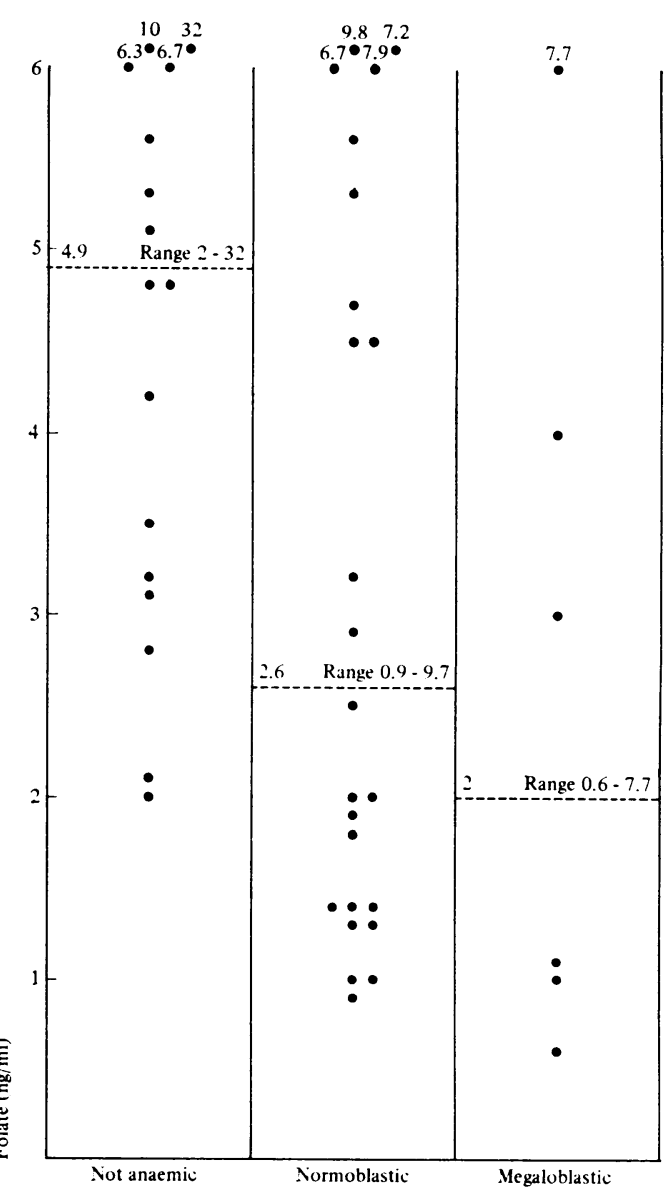

Fig. 2b

the birth weights. Statistical analysis of these figures, using the method set out in scientific tables (Documenta Geigy, 1965) for testing the significance of the difference between two means, shows that there is no significant difference in these values.

PLACENTAL WEIGHTS

Unlike the infant birth weights, the average placental weights in the various groups were identical (1lb $6 \mathrm{oz}$ ).

\begin{tabular}{|c|c|c|c|c|c|c|c|}
\hline \multirow{3}{*}{$\begin{array}{l}\text { Anaemia } \\
\text { Never anaemic } \\
\text { Normoblastic }\end{array}$} & \multicolumn{7}{|c|}{ Birth weight (lb oz) } \\
\hline & \multicolumn{2}{|c|}{ Para 0} & \multicolumn{2}{|c|}{ Para 1-4 } & \multicolumn{3}{|c|}{ Para 5+ } \\
\hline & $\begin{array}{rr}7 & 0 \\
6 & 9 \\
6 & 10\end{array}$ & $\begin{array}{c}(131)^{2} \\
(19) \\
(12)\end{array}$ & $\begin{array}{rr}7 & 2 \\
7 & 1 \\
6 & 13\end{array}$ & $\begin{array}{r}(140) \\
(26) \\
(20)\end{array}$ & $\begin{array}{l}7 \\
7 \\
7\end{array}$ & $\begin{array}{l}6 \\
4 \\
3\end{array}$ & $\begin{array}{l}(30) \\
(12) \\
(10)\end{array}$ \\
\hline
\end{tabular}

Table V Birth weights (median values) in iron-treated group.

${ }^{1}$ In 18 cases, the birth weight was not recorded, and 45 cases of unclassified anaemia have been omitted.

${ }^{2}$ Numbers of patients shown in brackets. 


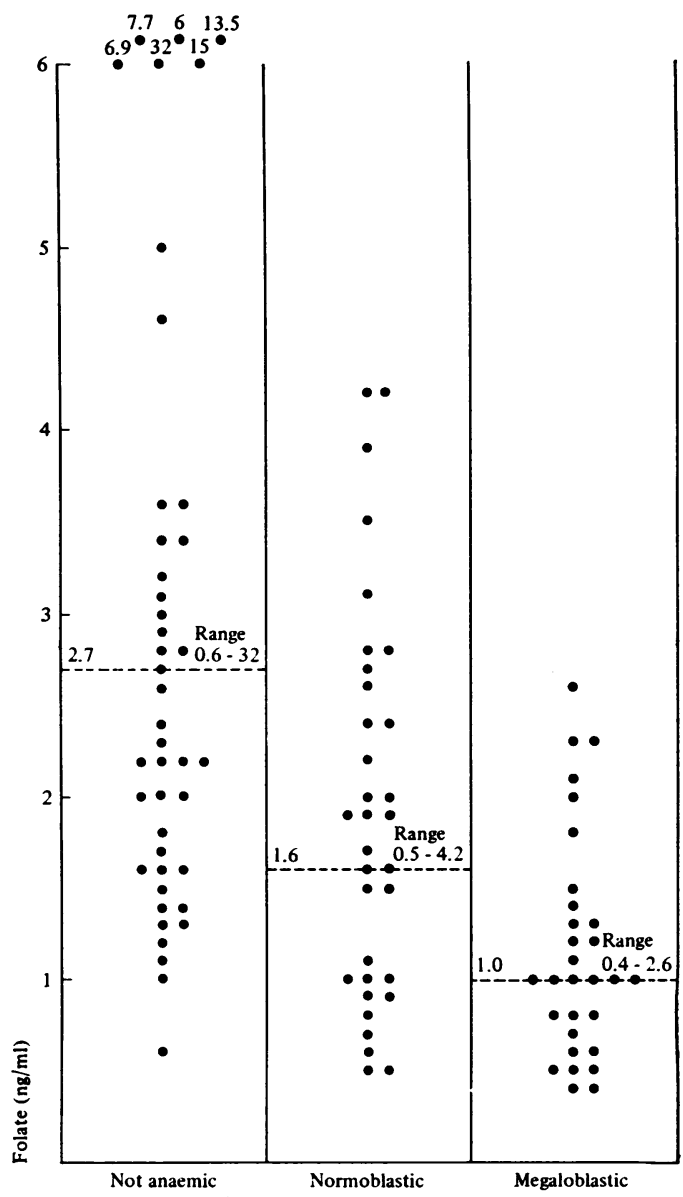

Fig 2c

\begin{tabular}{|c|c|c|c|}
\hline \multirow[t]{2}{*}{ Anaemia } & \multicolumn{3}{|c|}{ Birth Weight (lboz) } \\
\hline & Para 0 & Para 1-4 & Para 5+ \\
\hline $\begin{array}{l}\text { Never anaemic } \\
\text { Normoblastic } \\
\text { Megaloblastic }\end{array}$ & $\begin{array}{ccc}6 & 14 \cdot 6 & (131)^{2} \\
6 & 7 \cdot 3 & (19) \\
6 & 4 \cdot 3 & (12)\end{array}$ & $\begin{array}{ccc}7 & 1 & (140) \\
7 & 3.6 & (26) \\
6 & 15.8 & (20)\end{array}$ & $\begin{array}{rrr}7 & 4.5(30) \\
7 & 11.9(12) \\
7 & 3.4(10)\end{array}$ \\
\hline
\end{tabular}

Table VI Birth weights (arithmetic means) in iron-treated group

${ }^{1}$ In 18 cases the birth weight was not recorded, and 45 cases of unclassified anaemia have been omitted.

'Number of patients shown in brackets.

\section{Discussion}

RELIABILITY OF LABILE SERUM FOLATE AS A DIAGNOSTIC CRITERION OF MEGALOBLASTIC ER YTHROPOIESIS

As has already been shown, neither the total nor the labile serum folate level was a reliable diagnostic criterion of megaloblastic erythropoiesis; estimation of the labile fraction had no advantage over estimation of the total serum folate. Our work thus lends no support to the hypothesis that megaloblastic erythropoiesis in pregnancy is

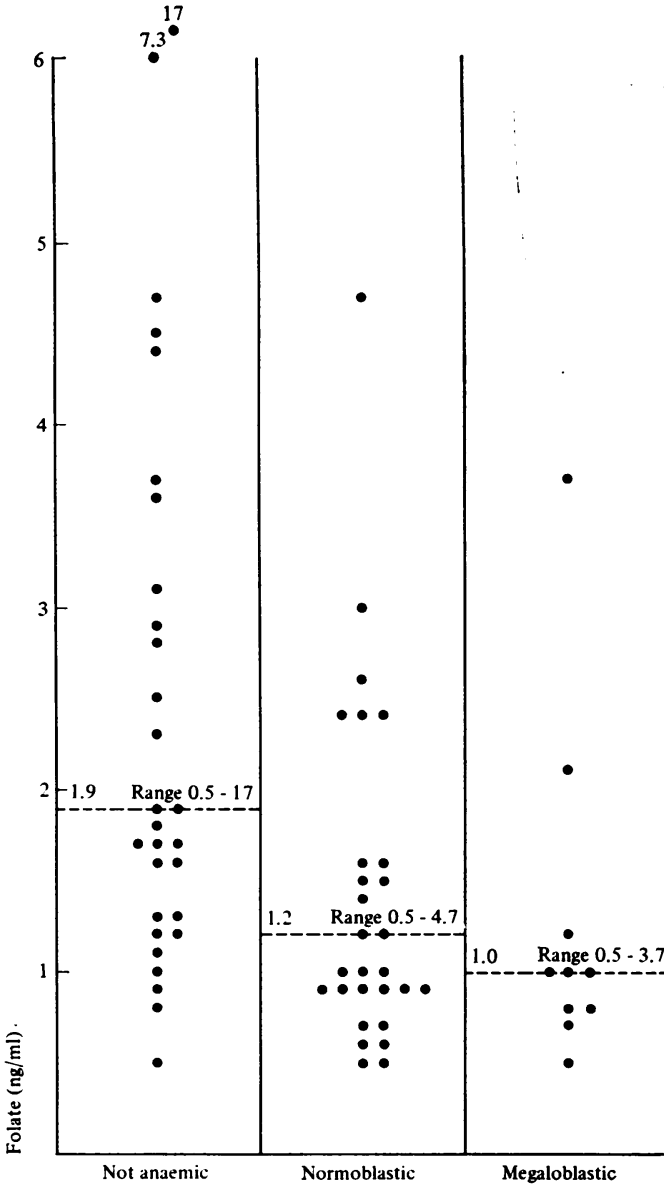

often due to an inability to metabolize folate compounds to the form in which they can be used Many of the women without anaemia or witi normoblastic anaemia had total and labile serum folate levels as low as those with megaloblastio anaemia. On the other hand, no serum taken at $\vec{a}$ time when the patient was known to have megaloo blastic anaemia contained more than $4 \mathrm{ng}$ per mi of total folate, and all but one contained less that $3 \mathrm{ng}$. We conclude that folate deficiency is commot in pregnancy but produces megaloblastic erythro poiesis in relatively few women-probably those whose folate deficiency is of long standing. (This is supported by the work of Temperley, Meehan and Gatenby (1968), who found that women whof developed megaloblastic erythropoiesis at termo had low serum folate levels early in pregnancy.)

INCIDENCE OF ALL TYPES OF ANAEMIA IN THE TWO GROUPS

Our findings show that the prophylactic use of folic acid together with iron reduces the incidence of normoblastic as well as of megaloblastic anaemia. It may be that normoblastic 


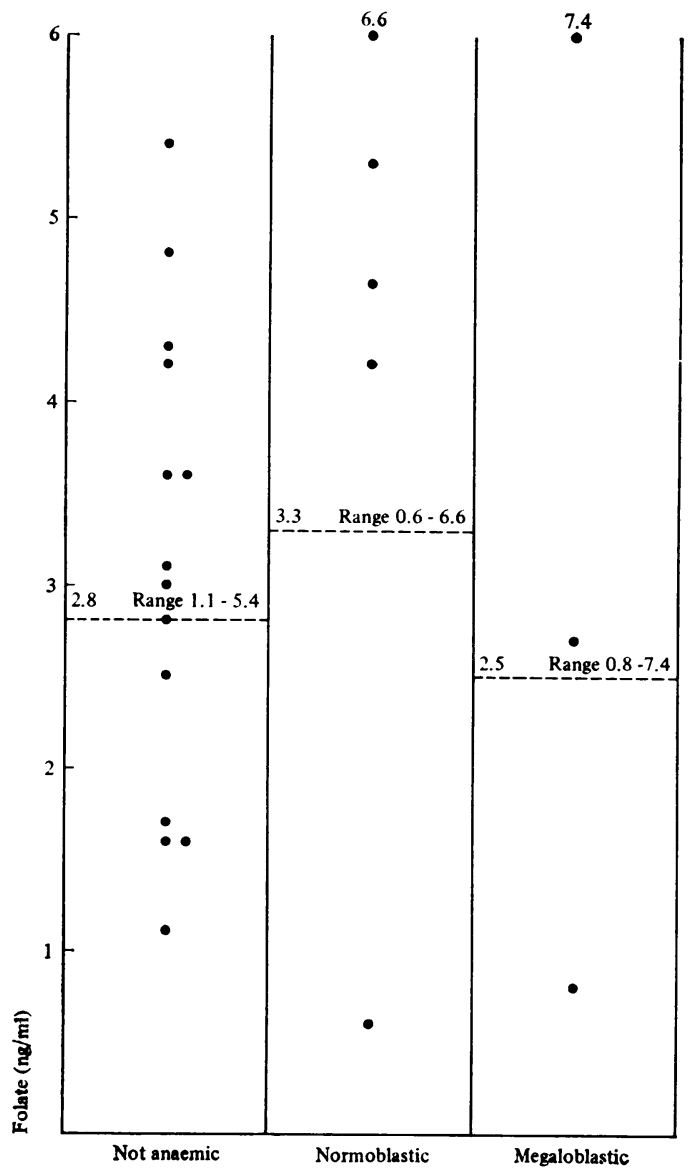

Fig. 3a

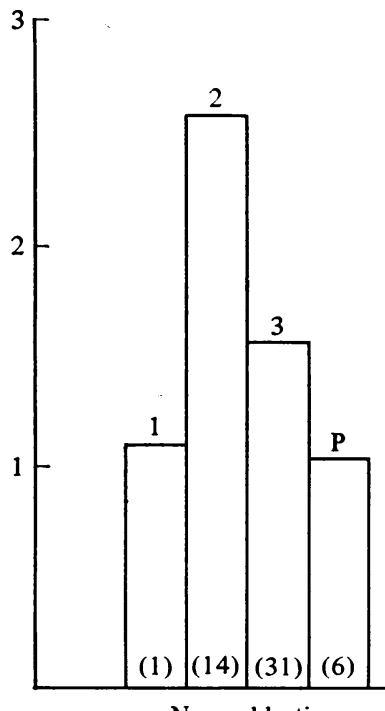

Normoblastic

Fig. 4a

(0)

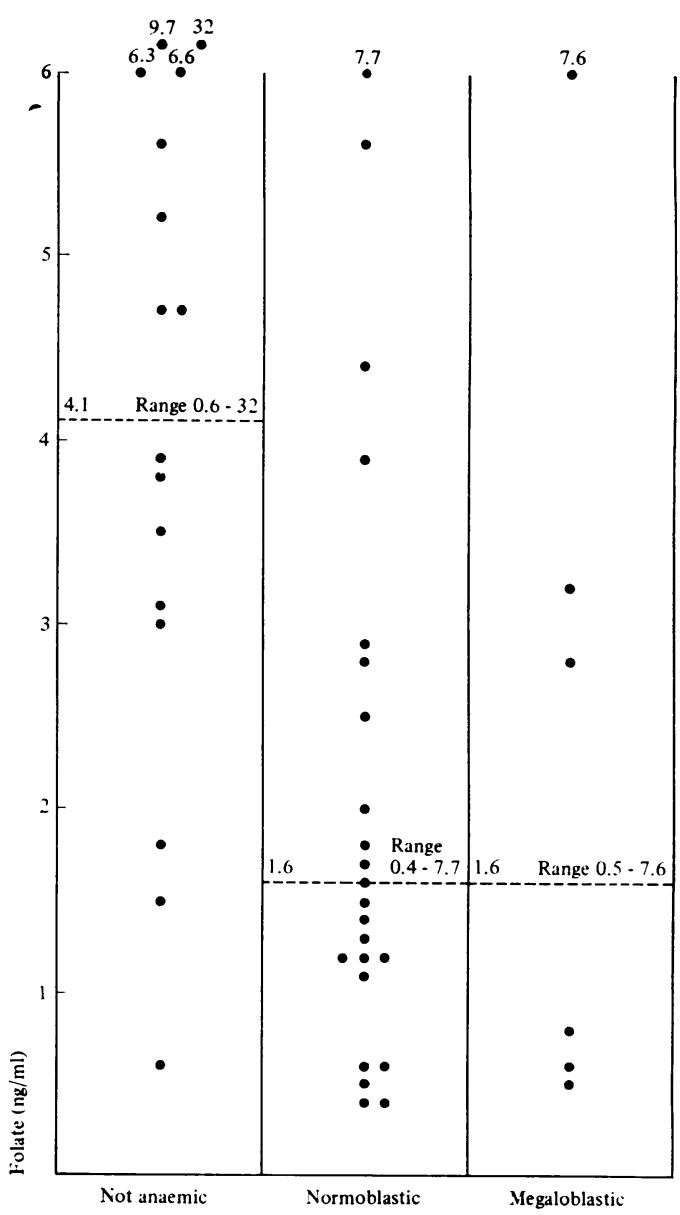

Fig. 3b

Fig. 3a, 3b, 3c, and 3d Labile serum folates in the various stages of pregnancy, grouped according to type of erythropoiesis. $3 a=$ first trimester, $3 b=$ second trimester, $3 c=$ third trimester, $3 d=$ puerperium. ('Normoblastic' and 'megaloblastic' refer to the patient's eventual classification; she did not necessarily have normoblastic (or megaloblastic) anaemia at the time the sample was taken.) Dotted line represents the geometric mean. As the diagram does not go above $6 \mathrm{ng}$ values above this level are marked at 6 with the actual level written above the dot.

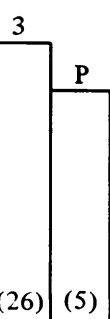

(1) (30) (10)

(0)

(0) (0) 


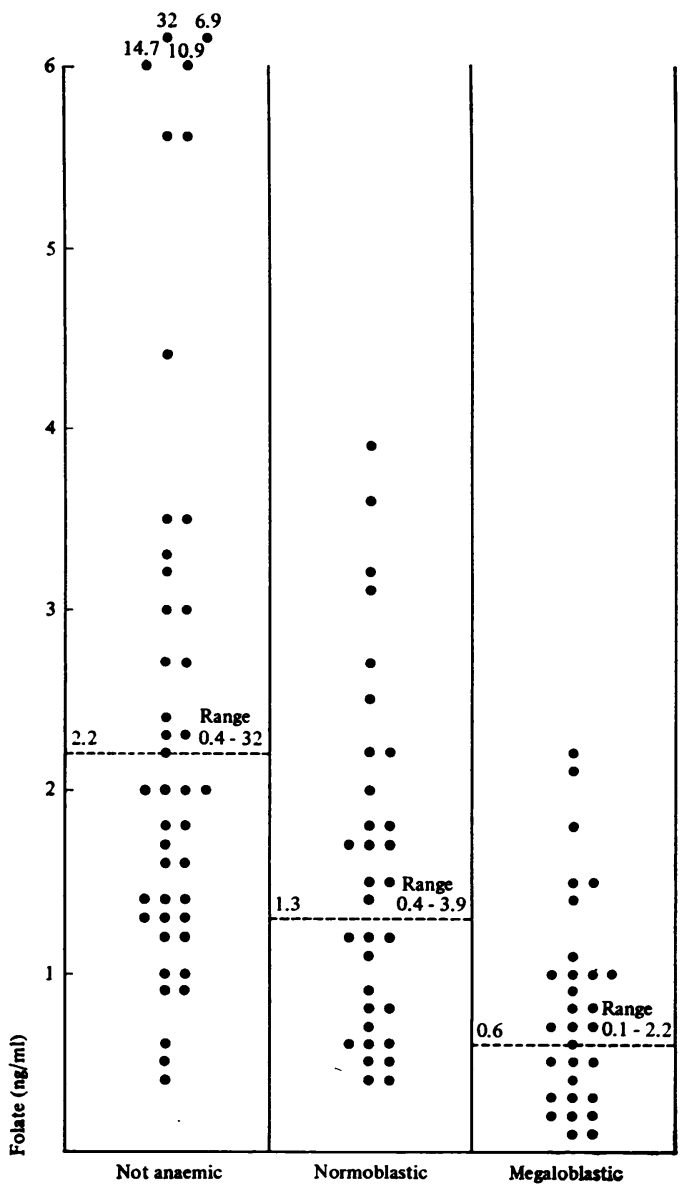

Fig. 3c.

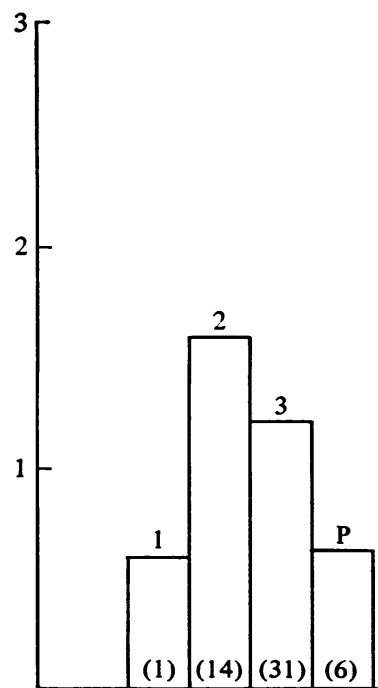

Normoblastic

Fig. 4b

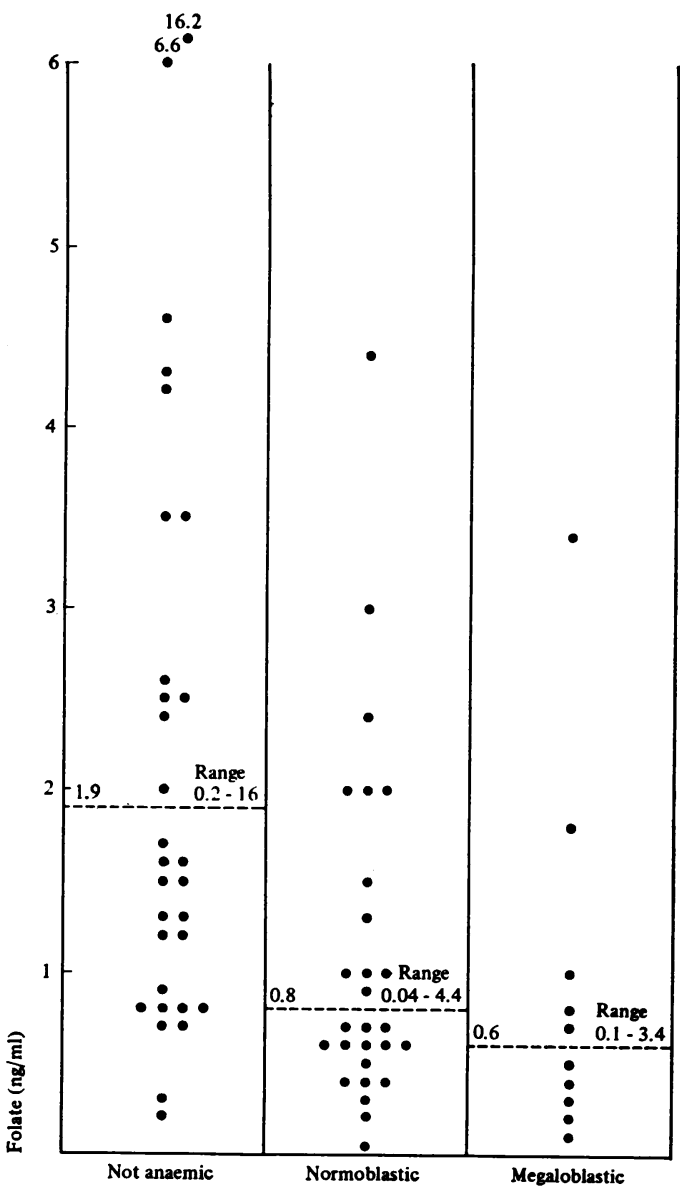

Fig. 3d.

Fig. 4a Geometric means of total serum folates grouped according to type of erythropoiesis, using only those sera taken at the same time as the marrow was aspirated. 1 = first trimester, 2 = second trimester, $3=$ third trimester, $P=$ puerperium.

Fig. 4b Geometric means of labile serum folates grouped according to type of erythropoiesis, using only those sera taken at the same time as the marrow was aspirated. 1 = first trimester, $2=$ second trimester, $3=$ third trimester, $P=$ puerperium. The figures in brackets denote the numbers of sera tested. 


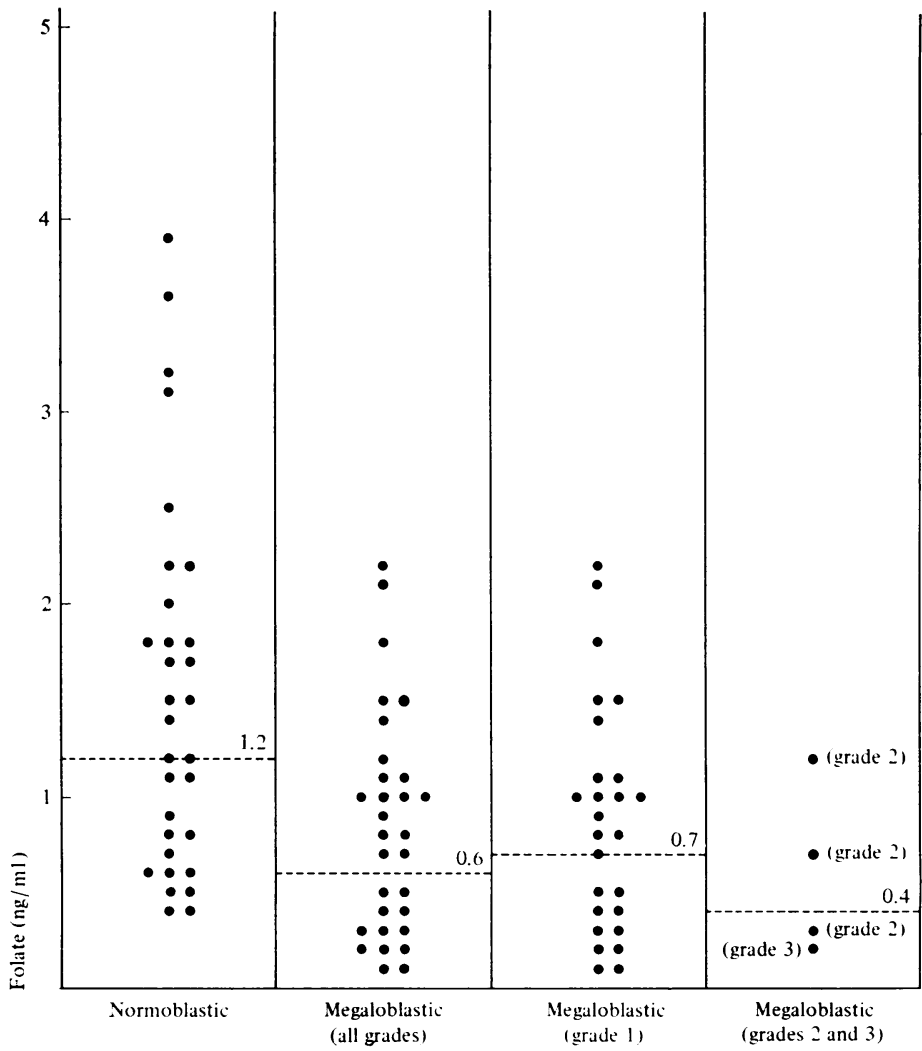

Fig. 5a.

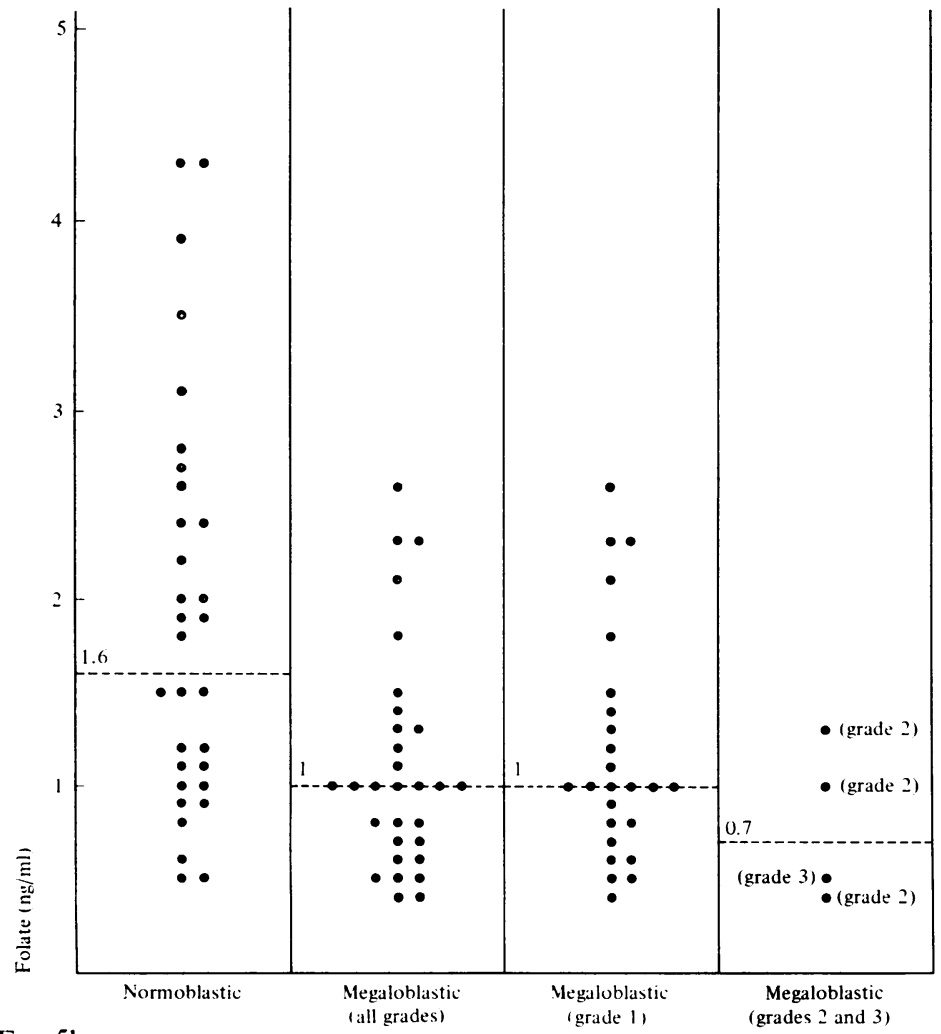

F g. 5b.
Figs. 5a and 5b Total (5a) and labile (5b) serum folates in the third trimester, grouped according to type of erythropoiesis, using only the sera taken at the same time as the marrow was aspirated. Dotted line represents the geometric mean.

anaemia is an earlier manifestation of folate lact and that if this lack continues long enough? megaloblastic anaemia will develop.

INCIDENCE OF OTHER SERIOUS COMPLICA TIONS OF PREGNANCY

We found no difference in the incidence of other complications of pregnancy between the patient with megaloblastic anaemia and the rest, excep $\bar{\phi}$ for accidental haemorrhage, where the incidenco was higher in the megaloblastic group. The numbee of patients involved was too small to admit of any firm conclusion being drawn about the relationship of megaloblastic anaemia and other complications of pregnancy.

RELATIONSHIP BETWEEN BLOOD GROUP AND MEGALOBLASTIC ERYTHROPOIESIS

We found the incidence of the various bloof groups to be the same in our patients wit megaloblastic anaemia as in the general popur lation. Our work therefore does not support th theory that there is an inherited tendency t $\vec{\sigma}$ megaloblastic erythropoiesis in women whose blood group is A (Giles, 1960).

ASSOCIATION OF MEGALOBLASTIC ANAEMI IN THE MOTHER WITH LOW BIRTH WEIGH IN THE BABY

Our findings, though not conclusive, suggest that there is a tendency for babies born of mothers with megaloblastic anaemia to have low birth weights. Since the placental weights of these्ष babies were not less than those of the others, ans adverse effect that maternal folate deficiency max have on the baby is probably mediated directl 8 on the foetus rather than indirectly by affectin placental growth. It would be of value to coms. pare infant birth weights with maternal and infan辛 folate levels. 

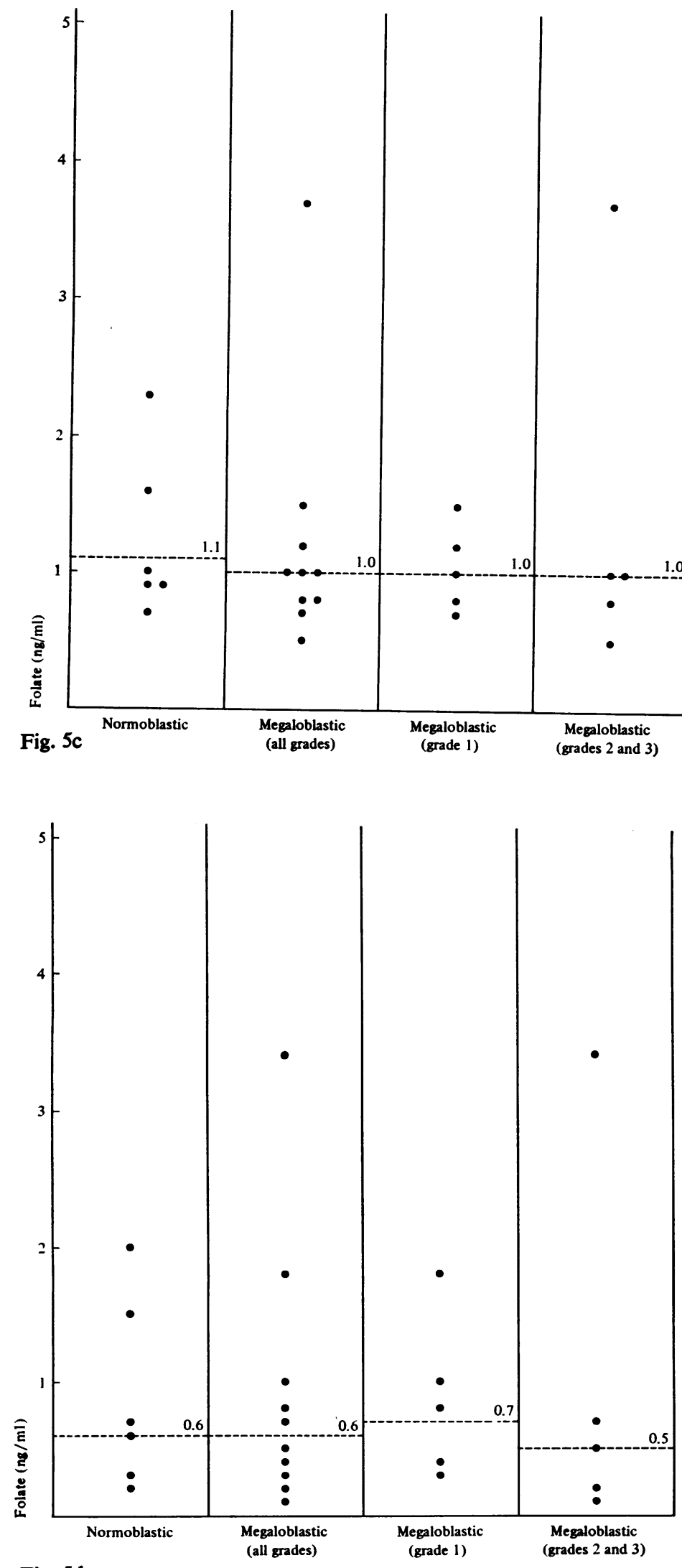

Figs. $5 \mathrm{c}$ and $5 \mathrm{~d}$ Total $(5 c)$ and labile $(5 d)$ serum folates in the puerperium, grouped according to type of erythropoiesis, using only sera taken at the same time as the marrow was aspirated. Dotted line represents the geometric mean.
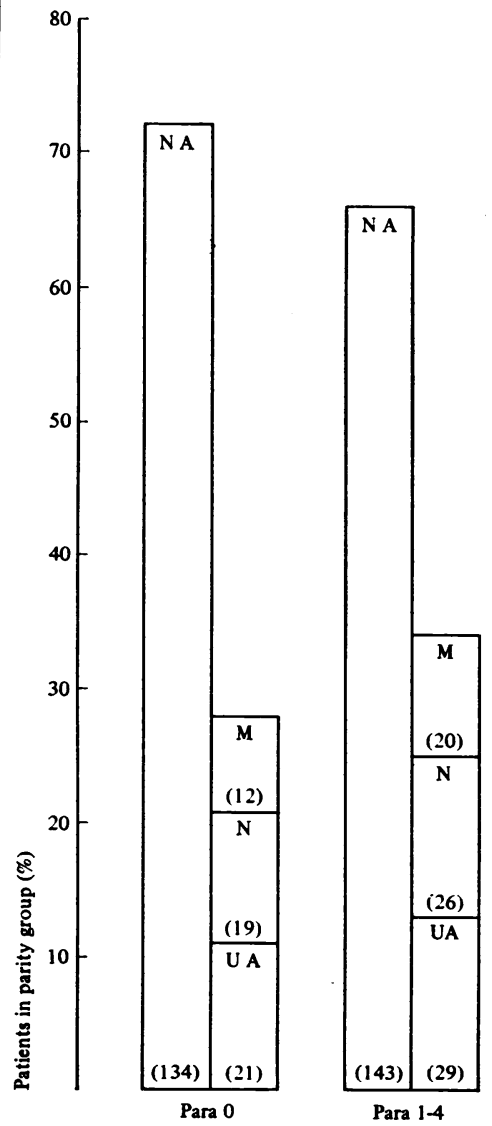

Fig. 6

Fig. 6 Relationship between parity and type of erythropoiesis. The anaemic column is subdivided into $M$ (megaloblastic), $N$ (normoblastic), and UA (unclassified) anaemia. The figures in brackets denote the actual numbers of patients, eg, 134 patients $(72 \%$ Fig. 5d of the para $O$ group) were not anaemic. 
We are grateful to Mr S. J. Barr and Mr J. K. P. Perera for allowing us access to their patients; to Mr F. Jones for establishing our modification of the assay method; to Messrs J. Keenan, I. Jones, A. Thomas, and Dr P. Fletcher for carrying out the assays; to $\mathrm{Mr}$ Tweedie, of the Liverpool University Medical Statistics Department, for help with the statistics; and to all the medical and nursing staff who have helped us in the collection of specimens and organization of the trial. The work was carried out with the aid of a grant from the Liverpool Medical Research Committee.

References

Ball, E. W., and Giles, C. (1964). Folic acid and vitamin $\mathbf{B}_{12}$ levels in pregnancy and their relation to megaloblastic anaemia. J. clin. Path., 17, 165-174.

Cowan, J. D., Hoff brand, A. V., and Mollin, D. L. (1966). Effect of serum-factors other than folate on the Lactobacillus casei assay. Lancet, 1, 11-14.

Dacie, J. V., and Lewis, S. M. (1963). Practical Haematology, 3rd ed., p. 326. Churchill, London.

Gatenby, P. B. B., and Lillie, E. W. (1960). Clinical analysis of 100 cases of severe megaloblastic anaemia of pregnancy. Brit. med. J., 2, 1111-1114.

Geigy, J. R. (1956). Scientific Tables (Documenta Geigy), p. 39, Geigy, Basle and Manchester.

Giles, C. (1960). Blood-group distribution in megaloblastic anaemia of pregnancy. Lancet, 2, 1063-1064.

Giles, C. (1966). An account of 335 cases of megaloblastic anaemia of pregnancy and the puerperium. J. clin. Path., 19, 1-11.

Hibbard, B. M., and Hibbard, E. D. (1963). Aetiological factors in abruptio placentae. Brit. med. J., 2, 1430-1436.

Hibbard, B. M., and Hibbard, E. D. (1968). Folate metabolism and reproduction. Brit. med. Bull., 24, 10-14.

Mackenzie, A., and Abbott, J. (1960). Megaloblastic erythropoiesis in pregnancy. Brit. med. J., 2, 1114-1116.

Martin, R. H., Harper, T. A., and Kelso, W. (1965). Serum-folicacid in recurrent abortions. Lancet, 1, 670-672.

Spray, G. H. (1964). Microbiological assay of folic acid activity in human serum. J. clin. Path., 17, 660-665.

Temperley, I. J., Meehan, M. J. M., and Gatenby, P. B. B. (1968). Serum folic acid levels in pregnancy and their relationship to megaloblastic marrow change. Brit. J. Haemat., 14, 13-19.

\section{Appendix}

METHOD OF ASSAY

\section{Preparation of Glassware}

The test tubes and Pasteur pipettes were boiled in the detergent Brilyanz, rinsed thoroughly with tap water and several changes of glass-distilled water, and dried in a hot air oven. After this initial washing, test tubes were filled with glassdistilled water, autoclaved, emptied, and hot air dried. All universal bottles used were new; their tops were removed, and the bottles and tops (with rubber liners in position) were boiled in distilled water twice, rinsed in distilled water, and dried in a warm place. Volumetric flasks and pipettes were not boiled but soaked in Brilyanz, washed in tap water, rinsed thoroughly with glass-distilled water, and hot air dried. Autopipetting syringes were squirted through with Brilyanz followed by tap water and glass-distilled water.
Collection of serum

Venous blood was taken into specially washed $\stackrel{\varrho}{=}$ Becton-Dixon Vacutainers; the serum was 7 separated within a few hours of its collection and $\stackrel{\text { P }}{5}$ divided equally between two plastic disposable으 bottles, ascorbic acid $(5 \mathrm{mg} / \mathrm{ml})$ being added to one but not the other; the paired sera were stored at $20^{\circ} \mathrm{C}$, and the two members of the pair were assayed at the same time. The labile fraction was $\underline{\bar{\sigma}}$ calculated by subtracting the stable fraction $\frac{\overline{\mathcal{S}}}{\bar{\sigma}}$ (estimated by assay of the serum without added $\stackrel{\varnothing}{\circledR}$ ascorbic acid) from the total serum folate (estimated by assay of the serum with added $\overrightarrow{0}$ ascorbic acid).

\section{Assay medium}

We used B.B.L. folic acid assay medium (obtain $\frac{?}{0}$ able from Kodak Ltd, Kirkby Trading Estate, i near Liverpool). This was made into $7.5 \%$ solution in distilled water and boiled. One dropw per cent of Tween 20 was added to the solution, $\widehat{C}$ which was then boiled for a further minute. One의 hundred $\mathrm{mg} \%$ ascorbic acid was added to themedium before use.

\section{Standard folic acid solution}

\section{Preparation of serum extracts}

Of the serum to be tested, $0.5 \mathrm{ml}$ was added toळे

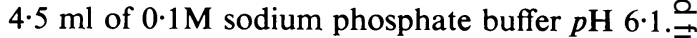
Ascorbic acid, $150 \mathrm{mg} \%$, was added to the buffero when the total serum folate was to be assayed but not when the labile fraction was to be estimated. The solution was autoclaved for two and a half minutes at $15 \mathrm{lb}$ psi, cooled, and $11 \mathrm{mlo}$ distilled water added to it (making 1/32 dilution: of serum). After mixing by gentle inversion, the solution was centrifuged to precipitate the pro- $\delta$ teins, and the clear extract was decanted ready for assay.

Assays were carried out in $5 \times \frac{1}{2}$ in. test tubes $>$ and were performed in duplicate at two dilutionso of each test serum, $1 \mathrm{ml}$ of serum extract plus $1 \mathrm{ml} / \mathrm{N}$ of distilled water being placed in each of two tubes and $2 \mathrm{ml}$ of serum extract with no distilled $\tilde{O}^{-}$ water in the remaining two. (Svendmyr pipetting ${ }_{\omega}^{N}$ syringes set at $1 \mathrm{ml}$ were used.)

\section{Preparation of standards}

A stock standard solution of pteroylglutamic? acid (Lederle), $1 \mathrm{mg} / \mathrm{ml}$, was made up by the method described by Dacie et al (1963). This was serially diluted in distilled water to give a dilution of $1 \mathrm{ng}$. From this, six working standards were $\overrightarrow{\mathbb{D}}$ prepared by serial doubling dilution in distilledo water, so that the final standards contained respectively $1.0,0.5,0.25,0.125,0.06$, and 0.030 millimicrograms of pteroylglutamic acid. Ones $\mathrm{ml}$ of each working standard was then placed info each of three tubes, and $1 \mathrm{ml}$ of distilled water 
added; each standard dilution was thus set up in triplicate.

Six blanks were also set up, each containing $2 \mathrm{ml}$ distilled water.

\section{Addition of medium}

Four ml of assay medium was added to the test sera, standards, and 'blanks', which were all then autoclaved for $5 \mathrm{~min}$ at $15 \mathrm{lb}$ psi.

\section{Inoculation and incubation}

When the tests, standards, and blanks had cooled after autoclaving, they were all (except one set of three blanks) inoculated with 1 drop of the bacterial suspension. All were then incubated for $\mathbf{4 0}$ hours at $37^{\circ} \mathrm{C}$. Two $\mathrm{ml} 10 \% \mathrm{HCl}$ was added to each tube, and the turbidity of each suspension was read in a nephalometer.

Preparation of bacterial suspension Lactobacillus casei (obtained from Scientific
Hospital Supplies Ltd, Liverpool), was main- $\complement$ tained in stab cultures of Difco micro-assay $\overline{\bar{J}}$ culture agar (B.319) and regularly subcultured 0 in Difco micro-inoculum broth (B.320). One such $\stackrel{0}{=}$ subculture was incubated overnight before the $\mathrm{O}$ assay; on the morning of the asasy, $15 \mathrm{ml}$ of folate- $\Rightarrow$ free assay medium was inoculated with one small $\stackrel{\rho}{?}$ platinum loop of the subculture, incubated at? $37^{\circ} \mathrm{C}$ for five to six hours, and used to inoculate tests and standards.

Reading the assays

The turbidity of the solution in the six standard tubes was read in the nephalometer. A graph was:then constructed, with pteroylglutamic acid con- $\vec{\omega}$ centration along one axis and bacterial growth? (as reflected in turbidity) along the other. Thiso standard curve was used to read off the folate ${ }_{\mathcal{E}}^{i}$ concentrations of the test sera. 